\title{
sciendo
}

Folia Oeconomica Stetinensia

Volume 21 (2021) Issue 1

DOI: $10.2478 /$ foli-2021-0007
WYDZIAL NAUK EKONOMICZNYCH I ZARZA_DZANIA

\section{MACROECONOMIC DETERMINANTS AFFECTING CREDIT RISK IN CENTRAL AND EASTERN EUROPE}

\author{
Anna Pluskota, MSc. \\ University of Lodz, \\ Faculty of Economics and Sociology, Department of Corporate Finance \\ Rewolucji Street 1905 r. no 39, 90-214 Lodz \\ e-mail: anna.pluskota@uni.lodz.pl \\ ORCID: 0000-0002-2566-3420
}

Received 28 March 2021, Accepted 12 April 2021

\begin{abstract}
Research background: A number of microeconomic and macroeconomic variables affect credit risk. Macroeconomic factors are particularly significant for credit risk volatility.

Purpose: The purpose of this study is to identify significant macroeconomic determinants influencing credit risk in the banking sector of Central and Eastern Europe. This goal was achieved as a result of a statistical and econometric analysis.

Research methodology: The empirical part includes a statistical study based on an analysis of primary statistics and Pearson's correlation coefficients between selected variables and the credit risk measure. Afterwards, on the basis of aggregated panel data at the country level, an econometric model was made through the GMM system.

Novelty: A statistical and econometric analysis was conducted that showed the occurrence of long-term shocks for credit risk for Central and Eastern European countries, which is in opposition to short-term shocks based on global credit risk studies. The stability of results for the impact of economic growth, unemployment rate and inflation rate on credit risk was confirmed. The occurrence of "moral hazard" in the banking sector of some of the examined countries was also proved. A comparison was made of the impact of macroeconomic variables on credit risk in particular examined countries. A considerable diversity of countries was demonstrated in terms of "moral hazard" in the banking sector.
\end{abstract}

Keywords: credit risk, economic growth, "moral hazard"

JEL classification: C22, E44 


\section{Introduction}

Microeconomic and macroeconomic factors affect credit risk. Usually, a special role is attached to the analysis of microeconomic factors such as the ratio of assets to bank capital, credit dynamics, risk management or the scale of the bank's activities. The ratio of assets to capital is particularly important due to the fact that the banks with a low capital level are exposed to a "moral hazard" (Berger, DeYoung, Genay, Udell, 2000). These factors have a direct impact on the amount of credit risk. However, analyzing the entire banking system in a global way, a number of factors from outside the banking system may be seen which also affect the size of credit risk in the sector, namely macroeconomic factors. From the point of view of understanding the causes of changes in the area of credit risk, attention should first be paid to the changes that have occurred in the area of macroeconomic determinants of credit risk.

Economic conditions significantly determine the creditworthiness of bank customers both enterprises and individuals. The degree of loan repayment by customers translates into credit risk and, as a consequence, affects the financial results of banks. The macroeconomic determinants of credit risk are included in the group of outside factors. Therefore, these factors do not depend on the bank's decision but affect their functioning. For the research area of Central and Eastern Europe and South-eastern Europe, it has been proved that both macroeconomic and microeconomic factors may explain credit risk, however, in case of the macroeconomic factors, low explanatory ability has been demonstrated (Klein, 2013).

The research covers the area of Central and Eastern Europe, including Poland, in 20082018. The obtained results were compared with previous studies carried out in the same research area, and particularly a comparison was made with the results obtained by (Klein, 2013), who analyzed the impact of selected macroeconomic factors on credit risk in Central and Eastern European countries. The empirical study includes a statistical analysis of collected data and an econometric analysis using the GMM system. The most important conclusions from the study indicate a highly significant impact of economic growth, unemployment rate and inflation on credit risk. It was also concluded that the shocks occurring in the area of credit risk are characterized by a long memory. Despite conducting the analysis on another research period, the results were highly consistent with those available in the literature. This means that the impact of the selected macroeconomic variables is stable for the examined countries in the long term. The correlation analysis made it possible to identify significant differences in the impact of individual variables on credit risk in each of the surveyed countries, in particular, major 
differences in the correlation between the rate of equity capital in total bank assets and credit risk between the surveyed countries was pointed out.

\section{Literature review}

Analyzing the scientific literature, which describes and studies the impact of macroeconomic factors on credit risk measures (Fallanca, Forgione, Otranto, 2021), diversity and a relatively wide range of the mentioned above variables might be observed. The selection of macroeconomic determinants varies depending on the research area and the period of analysis, although a certain set of determinants is universal (e.g. economic growth or interest rate), therefore, theoretical considerations were focused on the literature covering the area of Central and Eastern Europe and South-eastern Europe.

The literature analyzing the impact of macroeconomic factors concentrates mainly on the results of research and their conclusions. A detailed analysis of the impact of macroeconomic factors on credit risk was carried out by Klein on the basis of Central and Eastern Europe and South-eastern Europe in the years 2008-2011. An empirical analysis showed that in this period the credit risk measure (NPL indicator - share of impaired loans in total loans) was mainly influenced by macroeconomic indicators: changes in real GDP, unemployment rate, inflation, exchange rate and capital market volatility index (Klein, 2013). The dynamics of real GDP negatively affected credit risk that is real GDP growth led to a decrease in the NPL rate (Hada, Bărbuță-Mișu, Iuga, Wainberg, 2020, p. 4). Economic growth generally determines whether a given country has a positive or negative economic environment. In a situation where there is a positive economic growth, the income of enterprises and individual customers' increases, therefore the borrowers usually have the necessary funds to cover their liabilities.

Variables such as unemployment rate (Borsuk, 2017), inflation (Ćurak, Pepur, Poposki, 2013), exchange rates (Wdowiński, 2014; Castro, 2012) and the capital market volatility index (Klein, 2013) had a positive effect on value of credit risk, hence their increase will also result in an increase in the NPL rate. This is due to the fact that the increase in unemployment, inflation and foreign currency prices as well as the increase in the capital market volatility index leads to a decrease in the income of population and enterprises, which translates into a reduced creditworthiness of indebted persons. However, in case of the impact of foreign currency exchange rates and inflation, the conclusions of the study are ambiguous, as they may be adversely affected by credit risk. The negative impact of foreign currency exchange rates on credit risk may result from the increased competitiveness of domestic goods in relation to 
foreign goods (Zeman, Jurca, 2008, p. 12). Thus, the positive or negative impact of currency exchange rates depends on the balance of payments of a given country. The negative impact of inflation on NPL has been indicated among others by (Szarowska, 2018, p. 24), where this relationship was argued by the decreasing real value of debt as a result of inflation increase (Kjosevski, Petkovski, Naumovska, 2019, p. 1192). However, this rise in inflation must also be accompanied by a rise in wages, because when there are rigid wages and high inflation, the borrower's real incomes decrease significantly, which limits the creditworthiness and the possibility of regular debt repayment.

Macroeconomic factors of credit risk include also the long-term interest rate, stock indices, real estate prices or overall debt level (Sztaudynger, 2018, p. 160 after Castro, 2012). In case of an increase in long-term interest rate and overall debt, credit risk should increase, as these factors affect borrowers' creditworthiness. On the other hand, an increase in the value of stock indices and real estate prices will have a negative impact on credit risk, as this will increase the borrower's wealth.

Most frequently in the literature analysis it was possible to indicate the impact of factors such as economic growth, unemployment and inflation on credit risk. Relying on this assumption, the following research hypotheses might be made based on three main macroeconomic variables that affect credit risk:

H1. Economic growth has a negative impact on credit risk.

H2. Unemployment has a positive effect on credit risk.

H3. Inflation has a positive impact on credit risk.

Due to the inclusion of microeconomic factors in the study, the following research hypothesis regarding the impact of the selected microeconomic variable on credit risk may be made:

H4. In the banking sector from the Central and Eastern European group of countries, "moral hazard" may be diagnosed.

The already mentioned "moral hazard" is characteristic of those banks which have low capital level and therefore have more risky loan portfolios. As a consequence, an increase in credit risk in the near future can be observed.

A confirmation of the above research hypotheses will make it possible to identify whether, in the case of Central and Eastern European countries, the variables indicated in the hypotheses have a highly significant impact on the level of credit risk. A verification of the hypotheses will be based on statistical and econometric tests. 


\section{Description of the methodology and databases}

The verification of the research hypotheses was based on a statistical analysis of basic descriptive statistics and the Pearson's correlation coefficient, followed by econometric modeling for panel data. In the empirical analysis, an analogous methodology was used as that among others by (Klein, 2013), that is dynamic panel models (specifically, the GMM system was used):

$$
N P L_{i, t}=\alpha_{i, t}+\beta_{i, t} N P L_{i, t-1}+\gamma_{i, t} B_{i, t}+\mu_{i, t}
$$

where NPL is the logarithm of NPL indicator (similar to (Klein, 2013)), $B$ are independent variables (details are shown in formula No. 3), and $\mu$ is the error that may be written as follows:

$$
\mu_{i, t}=\delta_{i, t}+\gamma_{i, t}+\varepsilon_{i, t}
$$

where $\delta$ is the country-specific random effects, $\gamma$ is the random effects assigned to the period, and $\varepsilon$ is a random component with basic properties.

The above method will be used to verify the hypotheses based on the database collected for the countries of Central and Eastern Europe ${ }^{1}$ in the period from 2008 to 2018 . The research area was selected in view of the strong economic links between the countries of this region, which may also result in a similar impact of the overall economic situation of the state on credit risk. However, the research period was narrowed due to the availability of data necessary for the analysis.

The most popular measure of credit risk is the NPL rate (non-performing loans) that is the share of the value of non-performing loans in the total value of all loans. The increase in the NPL ratio enables to conclude that the quality of the loan portfolio has deteriorated. Despite some advantages resulting from the construction and interpretation of this measure, the literature indicates the most important disadvantages of NPL (Wdowiński, 2014 after Zeman, Jurca, 2008): the interpretation of the measure depends on the current definition of a nonperforming loan, this measure is retrospective, changes in the value of the measure must also be interpreted in the context of changes in the volume of loans, a decrease in the value of the measure may be associated with better quality loans in the overall pool or with the sale of some risky loans. The above comments on the indicator do not render its useless, as it still remains one of the most significant measures of credit risk, although, it should be remembered to interpret the values of the NPL indicator with some caution.

\footnotetext{
1 The countries selected for the study were Bulgaria, the Czech Republic, Estonia, Lithuania, Latvia, Poland, Romania, Slovakia, Slovenia and Hungary.
} 
On the basis of the literature analysis, macroeconomic indicators have been selected that may significantly affect credit risk in Central and Eastern Europe. Apart from the variables necessary to verify the research hypotheses, other auxiliary variables were also analyzed. The list of all variables used in the empirical study is as follows:

a) NPL - (source: World Bank - World Development Indicators) - non-performing loans;

b) Growth - (source: World Bank - World Development Indicators) - economic growth;

c) Unemployment - (source: World Bank - World Development Indicators) - percent of total labor force;

d) Inflation - (source: World Bank - World Development Indicators) - consumer prices (annual \%);

e) USD/EUR - (source: World Bank - World Development Indicators) - exchange rate USD/EUR;

f) Bonds - (source: Eurostat) - central government bond yields on the secondary market, gross of tax, with around 10 years' residual maturity;

g) Index (VIX) - (source: investing.com) - CBOE Volatility Index;

h) Debt - (source: World Bank - World Development Indicators) - Domestic credit to private sector by banks ( $\%$ of GDP);

i) Capital/Assets- (source: World Bank - World Development Indicators) -Bank capital to assets ratio $(\%)$.

The above data was subject to a statistical analysis based on the analysis of descriptive statistics and the Pearson's correlation coefficient. The descriptive statistics are presented in Table 1.

Table 1. Descriptive statistics for variables used in the empirical analysis (2008-2018)

\begin{tabular}{|l|c|c|c|c|r|r|}
\hline \multicolumn{1}{|c|}{ NPL } & Average & $\begin{array}{c}\text { Standard } \\
\text { error }\end{array}$ & Median & $\begin{array}{c}\text { Standard } \\
\text { deviation }\end{array}$ & Minimum & Maximum \\
\hline NPL & 7.28 & 0.58 & 5.21 & 5.47 & 0.45 & 23.99 \\
\hline Growth & 2.00 & 0.44 & 2.91 & 4.20 & -14.81 & 9.30 \\
\hline Unemployment & 9.00 & 0.39 & 7.85 & 3.66 & 2.39 & 19.48 \\
\hline Inflation & 2.51 & 0.31 & 2.20 & 2.93 & -1.54 & 15.40 \\
\hline USD/EUR & 1.26 & 0.01 & 1.29 & 0.12 & 1.05 & 1.44 \\
\hline Bonds & 3.98 & 0.30 & 3.83 & 2.69 & 0.31 & 14.00 \\
\hline Index (VIX) & 21.14 & 1.43 & 15.81 & 13.49 & 3.00 & 60.47 \\
\hline Debt & 54.03 & 1.67 & 51.19 & 15.70 & 25.93 & 100.78 \\
\hline Capital/Assets & 9.54 & 0.18 & 9.54 & 1.77 & 5.46 & 12.91 \\
\hline
\end{tabular}

Source: own study based on the GRETL package. 
Table 2. Pearson's correlation for selected variables (2008-2018)

\begin{tabular}{|l|c|c|c|c|c|c|c|c|}
\cline { 2 - 9 } \multicolumn{1}{c|}{} & NPL & Growth & $\begin{array}{c}\text { Unemploy- } \\
\text { ment }\end{array}$ & Inflation & USD/EUR & Bonds & $\begin{array}{c}\text { Index } \\
\text { (VIX) }\end{array}$ & Debt \\
\hline Growth & -0.24 & 1.00 & & & & & & \\
\hline Unemployment & 0.45 & -0.28 & 1.00 & & & & & \\
\hline Inflation & -0.09 & -0.06 & -0.15 & 1.00 & & & & \\
\hline USD/EUR & 0.18 & -0.45 & 0.35 & 0.50 & 1.00 & & & \\
\hline Bonds & 0.46 & -0.59 & 0.36 & 0.43 & 0.70 & 1.00 & & \\
\hline Index (VIX) & -0.16 & -0.06 & -0.07 & 0.75 & 0.48 & 0.42 & 1.00 & \\
\hline Debt & -0.03 & -0.43 & 0.40 & 0.18 & 0.25 & 0.30 & 0.18 & 1.00 \\
\hline Capital/Assets & -0.00 & 0.25 & 0.26 & -0.21 & -0.26 & -0.25 & -0.31 & 0.08 \\
\hline
\end{tabular}

Source: own study based on the GRETL package.

From the point of view of the conducted analysis, particularly important are the values of the Pearson's correlation coefficient for selected variables with the NPL ratio. All variables except the debt rate were highly correlated with the NPL ratio. The signs at the correlation coefficients were also in line with expectations, only the sign at the correlation coefficient for the NPL pair and index (VIX) was negative, although a positive sign was expected. In the period of analysis for the countries of Central and Eastern Europe, the increase in capital market volatility was associated with a decrease in the value of the credit risk measure. This situation may result from the low development of the capital market among the analyzed countries.

Pearson's correlation was analyzed for the NPL indicator and for all selected variables in a division of each of the 8 examined countries. The results are presented below in Table 3 .

Table 3. Pearson's correlation for selected variables with the NPL indicator, in a division of each of the examined Central and Eastern European countries

\begin{tabular}{|l|r|r|r|r|r|r|r|r|}
\cline { 2 - 8 } \multicolumn{1}{c|}{} & Bulgaria & $\begin{array}{c}\text { Czech } \\
\text { Republic }\end{array}$ & Estonia & Latvia & Lithuania & Poland & Romania & $\begin{array}{c}\text { Slovak } \\
\text { Republic }\end{array}$ \\
\hline Growth & -0.2156 & -0.1430 & -0.4167 & -0.4029 & $\mathbf{- 0 . 5 0 3 4}$ & $-\mathbf{0 . 5 5 9 2}$ & -0.2373 & -0.3260 \\
\hline Unemployment & 0.8635 & 0.7517 & 0.9486 & 0.9467 & 0.9230 & 0.6995 & 0.7195 & 0.8632 \\
\hline Inflation & $\mathbf{- 0 . 7 1 7 8}$ & $\mathbf{- 0 . 6 8 0 3}$ & 0.0408 & -0.3127 & 0.0436 & -0.1339 & -0.2054 & -0.3275 \\
\hline USD/EUR & -0.2686 & -0.0215 & $\mathbf{0 . 6 7 5 2}$ & 0.4301 & $\mathbf{0 . 7 0 5 6}$ & 0.1039 & 0.1276 & 0.1833 \\
\hline Bonds & -0.2087 & -0.1705 & 0.0000 & $\mathbf{0 . 7 4 4 5}$ & $\mathbf{0 . 8 1 1 2}$ & -0.0119 & -0.0893 & 0.2836 \\
\hline Index (VIX) & $\mathbf{- 0 . 7 1 7 4}$ & $\mathbf{- 0 . 5 1 3 4}$ & 0.2455 & -0.1066 & 0.0970 & $-\mathbf{0 . 6 5 1 6}$ & -0.4703 & -0.4607 \\
\hline Debt & -0.0375 & 0.1683 & $\mathbf{0 . 8 4 9 4}$ & $\mathbf{0 . 5 8 0 3}$ & $\mathbf{0 . 7 0 4 5}$ & 0.1297 & 0.3408 & -0.3376 \\
\hline Capital/Assets & -0.1644 & $\mathbf{0 . 6 8 6 2}$ & $\mathbf{- 0 . 7 5 3 5}$ & -0.2914 & -0.1564 & 0.0502 & $\mathbf{- 0 . 7 7 6 2}$ & 0.4642 \\
\hline
\end{tabular}

Strong correlation is marked in bold.

Source: own study. 
Based on the results of the correlation coefficient between the NPL ratio and selected variables, it may be pointed out that only in case of the variable describing the unemployment rate, a strong positive correlation occurs for data from all of the examined countries. The increase in unemployment with credit risk was most strongly correlated only in Lithuania and Poland. A strong correlation of inflation rate was proved only for Bulgaria and the Czech Republic. The correlation between credit risk and the USD/EURO exchange rate was strong for data from Estonia and Lithuania. The bond interest rate was strongly correlated with credit risk for data from Lithuania and Latvia. The measure of capital market volatility was strongly correlated with credit risk in Bulgaria, the Czech Republic and Poland. The debt rate proved to be strongly correlated with credit risk only for Estonia, Latvia and Lithuania. The variable describing the share of capital in the bank's assets was strongly correlated with credit risk in the Czech Republic, Estonia and Romania. The lack of harmonized results for all of the countries except for the correlation indicator for the unemployment rate means that the examined countries differ in terms of the correlation strength between credit risk and selected macroeconomic variables and one microeconomic variable. Only in the case of the correlation between the unemployment rate and credit risk there is a positive strong correlation meaning that as the unemployment rate increases, credit risk increases.

\section{Results of the empirical study}

The verification of the hypotheses was conducted on the basis of models estimated by the GMM system. Model instruments were model variables delayed by 1 period. The general form of the model is as follows (extended form of equation No. 1):

$$
\begin{aligned}
& N P L_{i, t}=\alpha_{i, t}+\beta_{1, t} N P L_{i, t-1}+\gamma_{1, t} \text { Growth }_{i, t}+\gamma_{2, t} \Delta \text { Unemployment }_{i, t}+ \\
& +\gamma_{3, t} \text { Inflation }_{i, t-1}+\gamma_{4, t} U S D / E U R_{i, t}+\gamma_{5, t} \text { Bonds }_{i, t}+
\end{aligned}
$$

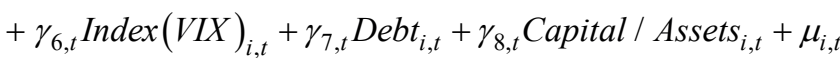

The results of the estimation are shown in Table 4, where four selected models were presented and on the basis of which further inferences were made. For each model four tests are presented to check their correctness AR(1), AR(2), the Sargan test and the Wald test, and the provided values of $\mathrm{p}$-value statistics allow to conclude that the models are correct. The values of the coefficients in each of the models for the explained variable delayed by 1 period are similar and range from 0.61 to 0.97 , which indicates a long period of impact of shocks related to this measure of credit risk on the entire banking system. The results are similar to those 
obtained by (Klein, 2013) based on the countries of Eastern, Central and South-eastern Europe in 1998-2011. The first research hypothesis assuming the positive impact of economic growth on reducing credit risk was verified on the basis of models 2, 3 and 4, where the coefficient for the variable of growth is negative (both in the direct impact version and in case of the impact delayed by 1 period). Similar results were obtained among others by (Klein, 2013; Wdowiński, 2014; Zeman, Jurca, 2008). The second research hypothesis was verified on the basis of models 2 and 3, which include the impact of unemployment (first differences) on NPL, and the coefficient for this variable is positive, that is consistent with the theoretical assumptions. In the case of model 1, the coefficient of the impact of unemployment on NPL is negative, which would suggest a decrease in credit risk due to an increase in the unemployment rate. Analogous results were obtained among others by (Wdowiński, 2014). The last research hypothesis concerned the positive impact of inflation on credit risk. In model 1, 2 and 3, the impact of inflation was delayed by 1 period on the NPL ratio, and the obtained model coefficients were positive and had an appropriate statistical significance, which allows verifying the third research hypothesis. These three main macroeconomic variables have a particularly important impact on the value of NPL, which might be justified on the basis of relatively high values of model coefficients and their high degree of statistical significance.

Table 4. Results of panel model estimation using the GMM system

\begin{tabular}{|c|c|c|c|c|}
\hline Variables & Model 1 & Model 2 & Model 3 & Model 4 \\
\hline $\operatorname{NPL}(\mathrm{t}-1)$ & $0.8218 * * *$ & $0.7428 * * *$ & $0.9792 * * *$ & $0.6153 * * *$ \\
\hline const & $-0.1025 * * *$ & $-0.0341^{* *}$ & $0.2477 * *$ & $-0.0645 * * *$ \\
\hline Growth & & $-0.0200 * *$ & $-0.0368 * * *$ & $-0.0328 * * *$ \\
\hline Growth $(\mathrm{t}-1)$ & -0.0025 & & & \\
\hline Unemployment & $-0.0579 * * *$ & & & \\
\hline$\Delta$ Unemployment & & $0.0439 * *$ & $0.0726 * * *$ & \\
\hline Inflation $(\mathrm{t}-1)$ & $0.0376 * * *$ & $0.0149 * * *$ & $0.0171 * *$ & 0.0015 \\
\hline USD/EUR & $-0.8349 * * *$ & $-0.5225^{* * *}$ & & \\
\hline Bonds & $0.0741 * * *$ & 0.0488 & & \\
\hline Index (VIX) & $-0.0114 * * *$ & -0.0016 & & \\
\hline Debt & 0.0013 & -0.0046 & & \\
\hline Capital/Assets & & -0.0166 & & \\
\hline Capital/Assets $(\mathrm{t}-1)$ & & & $-0.0172 *$ & $-0.0299 * *$ \\
\hline Test AR(1) p-value & 0.0052 & 0.1656 & 0.0000 & 0.0544 \\
\hline Test AR(2) p-value & 0.2289 & 0.3345 & 0.8541 & 0.5075 \\
\hline Sargan Test p-value & 0.1307 & 0.2349 & 0.0000 & 0.1506 \\
\hline Wald Test p-value & 0.0000 & 0.0000 & 0.0000 & 0.0000 \\
\hline
\end{tabular}

Significance levels for the parameters are given in the table: *** $\mathrm{p}<0.01, * * \mathrm{p}<0.05, * \mathrm{p}<0.1$.

Source: own study based on the GRETL package. 
Moreover, other macroeconomic variables explaining credit risk volatility were used in the models. The increase in the USD/EUR exchange rate had a negative impact on the NPL rate, which means that the weakening of the EURO against the USD had a positive effect on the decrease in credit risk. The depreciation of the Euro currency improves the economic situation of exporters due to the fact that the goods valued in Euro will be more competitive than those goods valued in USD. The increase in the interest rate on bonds resulted in an increase in the NPL rate, which is consistent with expectations, as the increase in interest rate is related to an increase in credit risk and reduces the creditworthiness of entities taking loans. The increase in the capital market volatility index was associated with a decrease in credit risk, which was already indicated when interpreting the Pearson's correlation coefficient for this pair of variables. The coefficient of debt to GDP had a positive impact on credit risk (the variable has no statistically significant impact), which was in accordance with expectations. The increase in the overall level of debt is related with an increase in the value of non-performing loans.

The impact of the microeconomic variable describing the share of capital in assets is statistically significant only for the variable delayed by 1 period (models 3 and 4 ). It is therefore possible to indicate that in the Central and Eastern European countries there was a "moral hazard" in the analyzed period, and thus a decrease in the share of equity in total assets resulted in an increase in credit risk. This phenomenon may be considered in the context of the results obtained in Table 3 for Pearson's correlation. A negative correlation between the share of equity in total assets and credit risk was demonstrated for Bulgaria, Estonia, Lithuania, Latvia and Romania (for Estonia and Romania it was a high correlation). However, it might be seen that in the Czech Republic the correlation between these variables was high but positive, which implies that there was no "moral hazard" in the case of this country. This points to a strong diversity between the analyzed countries in terms of banks' lending policy related to the amount of capital held in relation to assets.

\section{Discussion}

The above empirical study showed a high impact of the value of NPL delayed by 1 period, as it was from 0.61 to 0.97 (Table 4). These results are specific for a given research area, and for comparison, the values of this parameter in the range from 0.18 to 0.24 for the research conducted on the basis of 75 countries in 2005-2010 (Beck, Jakubik, Piloiu, 2013) might be given. This means that in the case of Central and Eastern European countries, shocks caused by the NPL variable affect the entire banking system in the long run; the share of non-performing 
loans in the total value of loans is an important measure in the analyzed area, which has a longterm impact on the situation of the entire sector. As far as the analyzed countries are concerned, a protection against shocks and immediate mitigation of emerging shocks in the area of nonperforming loans is particularly significant from the point of view of the entire banking system. Comparing the results obtained for the three main macroeconomic variables: economic growth, unemployment rate and inflation, it should be noticed that they are very much the same as those obtained by (Klein, 2013). Thus, it may be concluded that the impact of these macroeconomic variables on credit risk is stable and regardless of the adopted research period, similar results are obtained. This conclusion should be particularly pointed out as this is important information from the point of view of the country's economic policy, because economic development is directly related to the good quality of banks' loan portfolio. In the case of Central and Eastern European countries, the stable value of the non-performing loan portfolio is particularly significant due to the fact that all shocks in this area will affect the economy for many years to come. Credit risk management focused on limiting any sudden value jumps of the NPL rate becomes a key task securing the entire banking system. This situation may be observed on the example of data for Poland in 2008-2018 (data are presented in Table 5). In 2008, the NPL ratio for Poland was $2.82 \%$, while in 2009 it increased dramatically to $4.29 \%$, to reach $5.20 \%$ in 2012 . This change in the value of the NPL ratio of banks was related to the economic downturn which affected the countries of Central and Eastern Europe after the financial crisis of 2008. In 2018, the NPL ratio was still higher than its value in 2008, thus the quality of loans remains at a lower level. In the context of economic development, it should be noted that it is the high quality of loans that provides the opportunity to soothe the banks' lending policy and to stimulate economic

Table 5. Summary of selected variables for Poland in 2008-2018

\begin{tabular}{|c|c|c|c|c|}
\hline Date & NPL & Growth & Unemployment & Inflation \\
\hline 2008 & 2.82 & 4.25 & 7.12 & 4.16 \\
\hline 2009 & 4.29 & 2.82 & 8.17 & 3.80 \\
\hline 2010 & 4.91 & 3.61 & 9.64 & 2.58 \\
\hline 2011 & 4.66 & 5.02 & 9.63 & 3.24 \\
\hline 2012 & 5.20 & 1.61 & 10.09 & 0.99 \\
\hline 2013 & 4.98 & 1.39 & 10.33 & 0.05 \\
\hline 2014 & 4.82 & 3.32 & 8.99 & -0.87 \\
\hline 2015 & 4.34 & 3.84 & 7.50 & -0.66 \\
\hline 2016 & 4.05 & 3.06 & 6.16 & 2.08 \\
\hline 2017 & 3.94 & 4.94 & 4.89 & 1.81 \\
\hline 2018 & 3.85 & 5.15 & 3.67 & \\
\hline
\end{tabular}

Source: own study based on source data. 
development (Lepczyński, Penczar, 2016, p. 940). At the same time, it is important to note that since 2013 the value of the NPL ratio has been gradually decreasing, which suggests the implementation of the restructuring process of impaired loans in the Polish banking system.

\section{Conclusions}

When analyzing the impact of macroeconomic factors on credit risk in the countries of Central and Eastern Europe, it should be noted that there is a close relationship between the size of credit risk measures and the economic condition of the economy. The following variables have a particularly significant impact on credit risk: economic growth, unemployment rate and inflation. These variables describe the condition of a given economy in a global way and therefore enable an overall evaluation of the economic situation of the population and enterprises, and the quality of the loan portfolio of a given banking sector depends on the financial condition of borrowers. The impact of selected macroeconomic variables on credit risk is stable over time, as indicated with the example of the studies conducted so far in the literature and the results obtained in the above empirical study.

Credit risk remains a significant issue for scientific discussion and subject of research. The above study may be extended to include the impact of microeconomic factors on credit risk. Particularly, the quality of credit portfolio management by banks may be taken into consideration, as the decisions to tighten or liberalize the criteria for granting credit directly affect the amount of credit risk to which the bank is exposed. Globally, the overall value of credit risk in the entire banking sector depends on the credit decisions of individual banks. The conducted research also proved the differences between the impact of particular research variables on credit risk in the group of Central and Eastern European countries, even in the context of the occurrence of a "moral hazard". Continuing these considerations, a number of questions should be answered related to the reasons for the differences in the impact of macroeconomic and microeconomic variables on credit risk among countries from the research area.

\section{References}

Beck, R., Jakubik, P., Piloiu, A. (2013). Non-performing loans: what matters in addition to the economic cycle? ECB Working Paper Series, 1515. 
Berger, A.N., DeYoung, R., Genay, H., Udell, G.F. (2000). Globalization of Financial Institutions : Evidence from Cross-Border Banking Performance. In Finance and Economics Discussion Series, 4. DOI: 10.17016/feds.2000.04.

Borsuk, M. (2017). Wpływ czynników makroekonomicznych na poziom kosztów ryzyka kredytowego banków. Studia i Prace Kolegium Zarządzania i Finansów/Szkoła Główna Handlowa, 153, 49-62.

Castro, V. (2013). Macroeconomic determinants of the credit risk in the banking system: The case of the GIPSI. Economic Modelling, 31, 672-683.

Ćurak, M., Pepur, S., Poposki, K. (2013). Determinants of non-performing loans - evidence from Southeastern European banking systems. Banks and Bank Systems, 8 (1), 45-53.

Fallanca, M., Forgione, A.F., Otranto, E. (2021). Do the Determinants of Non-Performing Loans Have a Different Effect over Time? A Conditional Correlation Approach. Journal of Risk and Financial Management, 14 (1), 21. DOI: 10.3390/jrfm14010021.

Hada, T., Bărbuță-Mișu, N., Iuga, I.C., Wainberg, D. (2020). Macroeconomic Determinants of Nonperforming Loans of Romanian Banks. Sustainability, 12 (18), 7533. DOI: 10.3390/ su12187533.

Kjosevski, J., Petkovski, M., Naumovska, E. (2019). Bank-specific and macroeconomic determinants of non-performing loans in the Republic of Macedonia: Comparative analysis of enterprise and household NPLs. Economic research-Ekonomska istraživanja, 32 (1), 1185-1203. DOI: 10.1080/1331677X.2019.1627894.

Klein, N. (2013). Non-Performing Loans in CESEE: Determinants and Impact on Macroeconomic Performance. IMF Working Papers, 13 (72), 1. DOI: 10.5089/9781484318522.001.

Lepczyński, B., Penczar, M. (2016). Comparative Analysis of the Quality of Loans the Banking Sectors in Central Eastern Europe. Zeszyty Naukowe Uniwersytetu Szczecińskiego Finanse Rynki Finansowe Ubezpieczenia, 4 (4), 931-943. DOI: 10.18276/frfu.2016.4.82/1-77.

Szarowska, I. (2018). Effect of macroeconomic determinants on non-performing loans in Central and Eastern European countries. International Journal of Monetary Economics and Finance, 11 (1), 20-35. DOI: 10.1504/IJMEF.2018.090564.

Sztaudynger, M. (2018). Gospodarka narodowa. Gospodarka Narodowa, 4 (296), 155-177.

Wdowiński, P. (2014). Makroekonomiczne czynniki ryzyka kredytowego w sektorze bankowym w Polsce (Macroeconomic credit risk factors in Poland's banking sector). Gospodarka Narodowa, 4 (272), 55-77.

Zeman, J., Jurca, P. (2008). Macro Stress Testing of the Slovak Banking Sector. National Bank of Slovak Working Paper, 1, 1-26. 